Bangladesh J. Bot. 49(2): 329-334, 2020 (June)

\title{
CANOPY STRUCTURE AND ITS RELATIONSHIP WITH YIELD AND SYNCHRONY IN POD MATURITY OF MUNGBEAN (VIGNA REDIATA L.)
}

\author{
MMA MONDAL \\ Crop Physiology Division, Bangladesh Institute of Nuclear Agriculture, \\ Mymensingh, Bangladesh
}

Keywords: Debranching, Canopy stature, Synchrony in pod maturity, Mungbean

\begin{abstract}
Field experiments were conducted under sub-tropical condition during March-May of two consecutive years of 2013 and 2014 to assess the effect of different levels of debranching and spacing on synchronous pod ripening and yield of mungbean. The debranching levels were: (i) Category 1 [main stem (MS) with 4 branches per plant, control], (ii) category 2 (MS with three branches per plant), (iii) category 3 (MS with two branches per plant), (iv) category 4 (MS with one branch per plant) and (v) category 5 (only MS). Under recommended plant spacing $(30 \mathrm{~cm} \times 10 \mathrm{~cm})$, plants having MS with 3 branches produced the highest seed yield due to increased number of seeds per pod over category 1 . The lowest seed yield was recorded in category 5 (only MS plant) due to fewer number of pods per plant. When the optimum plant population per unit area according to canopy area was considered, it was estimated that the highest plants $/ \mathrm{m}^{2}$ was accommodated in MS only of 50 plants $/ \mathrm{m}^{2}$ showing the highest seed yield $(2570 \mathrm{~kg} / \mathrm{ha})$ followed by MS with one branch (40 plants $/ \mathrm{m}^{2}, 2460 \mathrm{~kg} / \mathrm{ha}$ ) and these two treatments also showed synchronous pod maturity. The lowest plant population per unit area was accommodated in MS with 3 and 4 branches $\left(25\right.$ plants $\left./ \mathrm{m}^{2}\right)$ and also showed lower seed yield (1910 and $1940 \mathrm{~kg} / \mathrm{ha}$, respectively) behaving asynchronous pod maturity.
\end{abstract}

\section{Introduction}

Mungbean [(Vigna radiata (L.) Wilczek] is an important pulse crop in Indian sub-continent and South-East Asia. It is considered as the quality pulse in the Indian subcontinent but asynchrony in pod maturity is a major problem in mungbean cultivation that is time consuming and adds cost to hand picking of pods (Tah and Saxena 2009). It has been observed that only about $65 \%$ of pods can be harvested in picking at $70-75$ days after sowing (DAS), $18 \%$ in the second harvest at $75-80$ DAS and 17\% in the third harvest at $90-95$ DAS (Mondal et al. 2011a). If all or more than $90 \%$ of total pods are harvested in a single harvest, the total harvesting cost can be lowered. Hence, genotypes with synchronized pod maturity are desirable. Further, approximately $55-85 \%$ of mungbean flowers do not develop into mature pods thereby showing low yield potential (Fakir et al. 2011). It is widely accepted that yield of leguminous crops can be increased, if abscission could be reduced. Mondal et al. (2011b) studied pod maturity synchrony in relation to flowering pattern in mungbean genotypes and reported that those genotypes which produced maximum flowers within 10 - 15 days after flowering begins (DAF) and ceased flowering within 15 - 20 DAF, showed synchrony in pod maturity but the authors did not study the morphological and architectural causes of asynchrony in flowering as well as asynchronous pod maturity in mungbean. Present study describes the relationship of synchrony/asynchrony in pod maturity with canopy structure in mungbean varieties. Such information may help for future plant breeding program.

In some situations, physical leaf area is adequate and even more than required in mungbean (Mondal et al. 2011c), but on the other hand, the functional efficiency is far lower due to utilizing resources as a respiratory burden of those parasitic leaves (in lower canopy) (Heuvelink 2005). Less number of branches up to certain limit may, therefore, be useful to overcome this problem

*Author for correspondence: <mmamondal@gmail.com>. 
of excessive vegetative growth. It is reported that narrow canopy stature improves light penetration inside the plant canopy and increases photosynthesis efficiency for fruit yield (Ambroszczyk et al. 2008). Since vegetative growth, a powerful sink, consumes produced assimilates and hence the limitation of vegetative growth enhances assimilate transport to fruits. Thus, proper balance between vegetative and reproductive growth could improve fruit setting percentage and quality (Arzani et al. 2009). There are some evidences that narrow canopy stature not only improve fruit quality but also increases plant health against pests and disease (Kanyomeka and Shivute 2005). The present experiment focused on investigating flower production, reproductive efficiency (pod set per cent) and degree of synchrony in pod maturity under different levels of debranching in profuse branch bearing mungbean to assess yield determining factors and synchronous pod maturity.

\section{Materials and Methods}

Two experiments were carried out at the experimental farm of Bangladesh Institute of Nuclear Agriculture, Mymensingh, Bangladesh $\left(24^{\circ} 75^{\prime} \mathrm{N}\right.$ and $\left.90^{\circ} 50^{\prime} \mathrm{E}\right)$ under subtropical condition during the two successive seasons (March-May) of 2013 and 2014. The experimental field was under subtropical climates characterized by heavy rainfall during the months of May to September and scanty rainfall during October to April. The soil of experimental site was sandy loam having a total nitrogen $0.065 \%$, organic matter $1.07 \%$, available phosphorus $18.5 \mathrm{ppm}$, exchangeable potassium $0.30 \mathrm{meq} / 100 \mathrm{~g}$, sulphur $20 \mathrm{ppm}$ and $\mathrm{pH} 6.8$.

The first experiment comprised of one factor randomized complete block design with three replications. The widely cultivated variety, BINAmung-7 was used as plant material. The debranching levels were: (i) Category 1 [Control, main stem (MS) with 4 branches per plant], (ii) category 2 (MS with three branches per plant), (iii) category 3 (MS with two branches per plant), (iv) category 4 (MS with one branch per plant) and (v) category 5 (only MS). The treatments were imposed when branches initiated and maintained the treatments until harvest. The unit plot size was $3 \mathrm{~m} \times 3 \mathrm{~m}$. To determine optimum spacing for different plant canopy (which developed by different levels of debranching), the second experiment was conducted in 2014. Four different plant spacings (which was determined based on the canopy structure of each treatment) such as 40 $\mathrm{cm} \times 10 \mathrm{~cm}, 30 \mathrm{~cm} \times 10 \mathrm{~cm}, 25 \mathrm{~cm} \times 10 \mathrm{~cm}$ and $20 \mathrm{~cm} \times 10 \mathrm{~cm}$ were maintained for the plant having main stem (MS) with 4 branches, MS with three branches, MS with two branches, MS with one branch and only MS, respectively. Plants were thinned within a line at 20 days after sowing (DAS) to maintain population $(25,25,30,40,50$ plants per square meter) according to treatment (Category 1, 2, 3, 4 and 5, respectively).

For the first experiment, seeds were sown on 3 March, 2013 in the experimental field with recommended spacing of $30 \mathrm{~cm} \times 10 \mathrm{~cm}$. In the second experiment, seeds were sown on 9 March, 2014 in the experimental field with different spacings. Urea, triple superphosphate, muriate of potash and gypsum were used as sources of nitrogen, phosphorus, potassium and sulphur at the rate of 40,120,80 and $30 \mathrm{~kg} / \mathrm{ha}$, respectively at the time of final land preparation (BARC 2005). First weeding was done followed by thinning at about 21 DAS. A single irrigation was given at 25 DAS in both years. Insecticide (Ripcord $50 \mathrm{EC}, 0.025 \%$ ) was sprayed at flowering and fruiting stage (55 DAS) to control shoot- and fruit borer. Other intercultural operations were done as and when required.

Five plants from each replication of the first experiment were randomly tagged for daily count of opened flowers. Flower count began from the date of opening of the first flower and continued daily until flowering ceased. The second rows from the border of each plot were used for sampling. For determination of total dry matter, the plants were separated into roots, stems, leaves and fruits, and the corresponding dry weight were recorded after oven drying at $80 \pm 2^{\circ} \mathrm{C}$ for 72 
hours. The total dry matter/plant was estimated by summing dry matter of leaves, stem, root and pods dry weight per plant. The leaf area was measured using automatic leaf area meter (Model: LICOR 3000, USA). The canopy area was measured using Ceptometer (Decagon Devices Inc., Pullman, WA, USA) at noon of sunny day at 71 DAS just before harvesting the pods. Harvest index was determined as: (grain yield/plot $\div$ biological yield/plot $) \times 100$. Per cent fruit set to opened flowers, reproductive efficiency $(\mathrm{RE})$ was estimated as: \% fruit set $=$ (Number of fruits/ plant $\div$ number of flowers/plant $) \times 100$. The degree of synchrony/asynchrony in pod maturity was determined as follows: Synchrony: $>90 \%$ pod matured; partial synchrony: 80 - 90\% pod matured and asynchrony: $<80 \%$ pod matured at 1st harvest (Mondal et al. 2011b).

At harvest, ten plants from each plot were selected randomly for data recording on total dry mass, reproductive efficiency, yield and yield related traits. Pod yield was measured from each plot excluding border line and converted into kilogram per hectare.

The collected data were analyzed statistically following the ANOVA technique and the mean differences among treatments were compared by DMRT using the statistical computer package program, MSTAT-C (Russell 1986).

\section{Results and Discussion}

The effect of different levels of debranching on number of leaves, leaf area (LA), leaf and pod size, and canopy area (CA) was significant and plant height did not differ significantly (Table 1). Result showed that number of leaves, LA and CA per plant decreased with increasing debranching levels over control, whereas reverse trend was in case of leaf size. The highest number of leaves per plant (17.5), LA per plant $\left(1833 \mathrm{~cm}^{2}\right)$ and CA per plant $\left(420 \mathrm{~cm}^{2}\right)$ was recorded in control plants (MS +4 branches) followed by the plants having mainstem (MS) with 3 branches with same statistical rank. In contrast, the lowest above parameters was recorded in the plants having MS only. The pod length was greater in plant with less number of branches than high branch bearing plant. However, plant height had no significant differences in the plants having any number of branches. Higher branch bearing plants (Control plant) produced smaller size of fruits than in plants with less number of branches might be due to plants having high number of branches continued to partition carbohydrates to vegetative growth, instead of reproductive growth. This result is consistent with Davis and Estes (1993) who reported that larger fruits produced in pruned plants than in non-pruned plants in tomato. In other words, plants having less number of branches produced fewer fruits than plants having higher number of branches (Table 3) that might be helped less competition for plant products to assimilate amongst the fruits and this has certainly facilitated increase fruit size (Mondal et al. 2011d).

Results indicated that there had significant different in physiological parameters such as biological yield (BY) per plant, harvest index (HI) and reproductive characters such as number of racemes and scars per plant except reproductive efficiency (RE) due to different levels of debranching (Table 2). Results showed that BY, number of racemes, scars and flowers per plant decreased with increasing debranching levels, whereas reverse trend was observed in case of $\mathrm{HI}$ and RE. The lowest number of racemes (14.47) and scars (53.1) per plant, and BY per plant (14.79 g) was recorded in uniculm plants (having MS only). In contrast, the highest number of racemes and scars per plant, and BY per plant was recorded in category 1 (MS +4 branches) followed by category 2 (MS with 3 branches). In general, heavy pruning (category 4 and 5) decreased the number of flowers but RE is not significantly affected by heavy pruning, even apparently increased over category 1,2 and 3). This could be explained in a way that less competition for assimilates by having fewer flowers and this has certainly facilitated to produce maximum number of fruits to flowers and vice versa (Mondal et al. 2011a). Since vegetative growth, as a powerful sink, consumes produced assimilates, limitation of vegetative growth 
enhances produced assimilate transport to fruits. Thus, proper balance between vegetative and reproductive growth could improve fruit setting percentage and quality (Arzani et al. 2009). In the present experiment, similar phenomenon might have happened in the fewer branches bearing plant and increased RE. Pruning increased $\mathrm{HI}$ indicating dry matter partitioning to economic yield is better in less branch bearing plant than in profuse branch bearing plant.

Table 1. Effect of debranching on morphological characters in mungbean cv. BINAmung-7.

\begin{tabular}{lcccccc}
\hline Treatments & $\begin{array}{c}\text { Plant height } \\
(\mathrm{cm})\end{array}$ & $\begin{array}{c}\text { Leaves/ } \\
\text { plant }(\text { no. })\end{array}$ & $\begin{array}{c}\text { Leaf area/ } \\
\text { plant }\left(\mathrm{cm}^{2}\right)\end{array}$ & $\begin{array}{c}\text { Single leaf } \\
\text { area }\left(\mathrm{cm}^{2}\right)\end{array}$ & $\begin{array}{c}\text { Canopy area/ } \\
\text { plant }\left(\mathrm{cm}^{2}\right)\end{array}$ & $\begin{array}{c}\text { Pod length } \\
(\mathrm{cm})\end{array}$ \\
\hline MS + 4 br (Cont.) & 38.6 & $17.5 \mathrm{a}$ & $1833 \mathrm{a}$ & $104.7 \mathrm{~b}$ & $420 \mathrm{a}$ & $7.07 \mathrm{~b}$ \\
MS + 3 br & 38.6 & $16.3 \mathrm{a}$ & $1786 \mathrm{a}$ & $109.6 \mathrm{~b}$ & $420 \mathrm{a}$ & $7.27 \mathrm{a}$ \\
MS + 2 br & 39.6 & $10.5 \mathrm{~b}$ & $1512 \mathrm{~b}$ & $144.0 \mathrm{a}$ & $310 \mathrm{~b}$ & $7.23 \mathrm{a}$ \\
MS + 1 br & 40.0 & $8.0 \mathrm{c}$ & $1250 \mathrm{c}$ & $156.2 \mathrm{a}$ & $250 \mathrm{c}$ & $7.20 \mathrm{a}$ \\
MS only & 39.7 & $5.1 \mathrm{c}$ & $750 \mathrm{~d}$ & $150.0 \mathrm{a}$ & $205 \mathrm{~d}$ & $7.21 \mathrm{a}$ \\
F test & $\mathrm{NS}$ & $* *$ & $* *$ & $* *$ & $* *$ & $*$ \\
CV $(\%)$ & 3.44 & 5.61 & 4.33 & 5.12 & 3.89 & 2.44 \\
\hline
\end{tabular}

In a column, same letter ( $\mathrm{s}$ ) do not differ significantly at $\mathrm{p} \geq 0.05$ by DMRT; $b r=$ Branch; MS = Mainstem. *, ** significant at 5 and $1 \%$ level of probability, respectively; NS = Not significant.

Table 2. Effect of debranching on physiological and reproductive characters in mungbean cv. BINA mung-.7

\begin{tabular}{lcccccc}
\hline Treatments & $\begin{array}{c}\text { Biological } \\
\text { yield/ plant (g) }\end{array}$ & $\begin{array}{c}\text { Harvest } \\
\text { index (\%) }\end{array}$ & $\begin{array}{c}\text { Racemes/ } \\
\text { plant (no.) }\end{array}$ & $\begin{array}{c}\text { Scars/ plant } \\
\text { (no.) }\end{array}$ & $\begin{array}{c}\text { Flowers/ } \\
\text { plant (no.) }\end{array}$ & $\begin{array}{c}\text { Reproductive } \\
\text { efficiency }(\%)\end{array}$ \\
\hline MS + 4 br (Cont.) & $37.32 \mathrm{a}$ & $30.39 \mathrm{c}$ & $17.7 \mathrm{a}$ & $116.2 \mathrm{a}$ & $63.8 \mathrm{a}$ & 62.3 \\
MS + 3 br & $31.39 \mathrm{~b}$ & $34.34 \mathrm{~b}$ & $17.7 \mathrm{a}$ & $116.1 \mathrm{a}$ & $60.0 \mathrm{a}$ & 64.0 \\
MS + 2 br & $25.47 \mathrm{c}$ & $34.86 \mathrm{~b}$ & $13.9 \mathrm{~b}$ & $90.4 \mathrm{~b}$ & $47.4 \mathrm{~b}$ & 63.6 \\
MS + 1 br & $20.63 \mathrm{~d}$ & $35.68 \mathrm{~b}$ & $11.0 \mathrm{c}$ & $74.9 \mathrm{c}$ & $40.9 \mathrm{~b}$ & 66.2 \\
MS only & $14.79 \mathrm{e}$ & $38.27 \mathrm{a}$ & $7.5 \mathrm{~d}$ & $53.1 \mathrm{~d}$ & $27.0 \mathrm{c}$ & 68.5 \\
F test & $* *$ & $* *$ & $* *$ & $* *$ & $* *$ & $\mathrm{NS}$ \\
CV $(\%)$ & 6.23 & 8.21 & 6.11 & 7.42 & 20.11 & 17.52 \\
\hline
\end{tabular}

In a column, same letter(s) do not differ significantly at $\mathrm{p} \geq 0.05$ by DMRT; br $=$ Branch; MS = Main stem. *, ** significant at 5 and $1 \%$ level of probability, respectively; NS = Not significant

The effect of different levels of debranching on yield and yield contributing characters was significant except 100-seed weight (Table 3). Results showed that seed yield per plant as well as seed yield per hectare and number of pods per plant increased in category 2 (plants of MS with 3 three branches) over category 1 (control plant) and further increasing debranching levels decreased number of pods and seed yield. The number of seeds per pod and 100-seed weight was higher in debranched plant than in control plant (category 1, MS +4 branches), but within the different levels of debranching did not differ significantly. The plant having MS with 3 branches (category 2) produced the highest seed yield ( $12.21 \mathrm{~g} /$ plant) followed by MS with 4 branches (category 1) with same statistical rank. The seed yield was the highest in plant having MS with 3 branches due to increase number of seeds per pod. Although the uniculm plants had larger fruit size than branch bearing plants, the fruit yield was the lowest in uniculm plant due to fewer fruits per plant and uniculm plants also showed the highest harvest index. 
Optimum row spacing ensures proper growth of the aerial and underground parts of the plant through efficient utilization of solar radiation, nutrients, land as well as air spaces and water. There are two general concepts to describe the relationship between plant density and seed yield (Singh et al. 2011). Firstly, irrespective of plant spacing within and among rows, plant density must be such that the crop develops a canopy able to intercept more than $95 \%$ of the incoming solar

Table 3. Effect of debranching on degree of synchrony in pod ripening, yield attributes and yield in mungbean cv. BINA mung-7.

\begin{tabular}{|c|c|c|c|c|c|c|c|}
\hline Treatments & $\begin{array}{l}\text { Pods/ } \\
\text { plant } \\
\text { (no.) }\end{array}$ & $\begin{array}{l}\text { Seeds/ } \\
\text { pod } \\
\text { (no.) }\end{array}$ & $\begin{array}{l}\text { 100-seed } \\
\text { weight } \\
(\mathrm{g})\end{array}$ & $\begin{array}{c}\text { Seed } \\
\text { weight/ } \\
\text { plant }(g)\end{array}$ & $\begin{array}{c}\text { Seed } \\
\text { yield } \\
(\mathrm{kg} / \mathrm{ha}) \dagger\end{array}$ & $\begin{array}{l}\text { Estimated plants/ } \\
\mathrm{m}^{2} \text { (no.) based on } \\
\text { canopy area }\end{array}$ & $\begin{array}{c}\text { Degree of } \\
\text { synchrony in } \\
\text { pod ripening }\end{array}$ \\
\hline MS + 4 br (Cont.) & $39.7 \mathrm{a}$ & $11.23 \mathrm{~b}$ & 3.41 & $12.05 \mathrm{a}$ & $2030 \mathrm{a}$ & 25 & Asynchrony \\
\hline $\mathrm{MS}+3 \mathrm{br}$ & $38.4 \mathrm{a}$ & $11.83 \mathrm{a}$ & 3.45 & $12.21 \mathrm{a}$ & $2060 \mathrm{a}$ & 25 & Asynchrony \\
\hline $\mathrm{MS}+2 \mathrm{br}$ & $30.3 \mathrm{c}$ & $11.63 \mathrm{a}$ & 3.49 & $9.84 \mathrm{~b}$ & $1870 \mathrm{ab}$ & 30 & Partial synchrony \\
\hline $\mathrm{MS}+1 \mathrm{br}$ & $27.1 \mathrm{c}$ & $11.63 \mathrm{a}$ & 3.56 & $8.98 \mathrm{~b}$ & $1670 \mathrm{~b}$ & 40 & Synchrony \\
\hline MS only & $18.5 \mathrm{~d}$ & $11.73 \mathrm{a}$ & 3.53 & $6.13 \mathrm{c}$ & $1020 \mathrm{c}$ & 50 & Synchrony \\
\hline$F$ test & $* *$ & $*$ & NS & $* *$ & $* *$ & - & \\
\hline $\mathrm{CV}(\%)$ & 10.56 & 4.25 & 3.10 & 8.44 & 7.31 & - & \\
\hline
\end{tabular}

In a column, same letter(s) do not differ significantly at $\mathrm{P} \geq 0.05$ by DMRT; br $=$ Branch; MS = Main stem. *, ** significant at 5 and $1 \%$ level of probability, respectively; NS = Not significant; Synchrony: $>90 \%$ pod matured; Partial synchrony: 80 - 90\% pod matured and asynchrony: < 80\% pod matured at 1 st harvest. $\dagger$ : Under recommended spacing of $30 \mathrm{~cm} \times 10 \mathrm{~cm}$.

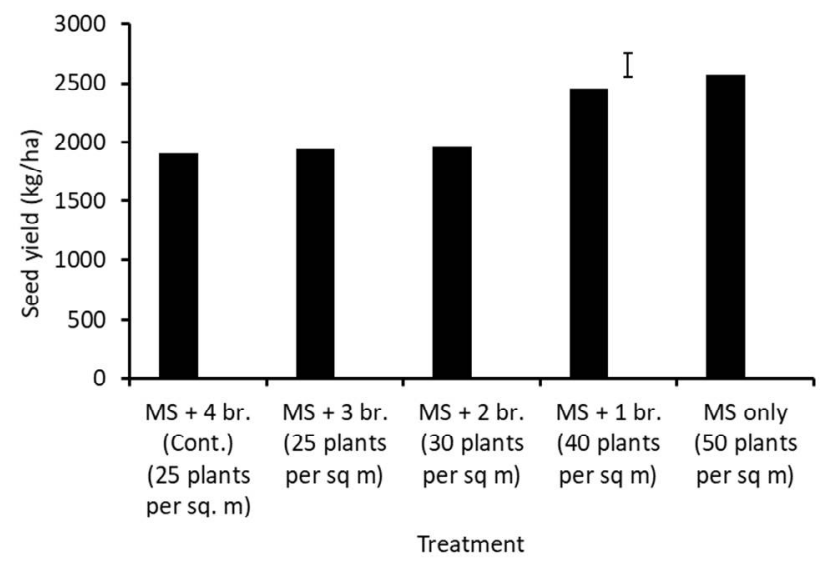

Fig. 1. Seed yield (kg/ha) under different plant densities (plant density calculated based on canopy area). Vertical bar represents LSD (0.05).

radiation during reproductive growth and secondly, a nearly equidistant plant arrangement minimizes interplant competition and produces maximum seed yield. The optimum row spacing for higher yield depends on canopy area of a cultivar. Therefore, the 2nd experiment was conducted to standardize optimum row spacing for maximizing seed yield of the created different types of canopy size. When the optimum plant population per unit area for different treatments is considered, the highest number of plants $/ \mathrm{m}^{2}$ (50 plants) was accommodated in MS only and this uniculm plants also showed the highest seed yield per unit area $(2570 \mathrm{~kg} / \mathrm{ha})$ followed by MS with one branch (40 plants $/ \mathrm{m}^{2}$ and $2460 \mathrm{ka} / \mathrm{ha}$ ) (Fig. 1). The lowest plant population per unit area was 
accommodated in MS with 3 and 4 branches $\left(25\right.$ plants $\left./ \mathrm{m}^{2}\right)$ and also showed lower seed yield per hectare (1910 and $1940 \mathrm{~kg} / \mathrm{ha}$, for MS with 3 and 4 branches, respectively). Seed yield per unit area increased in the plants having narrow canopy (category 4 and 5) might be due to higher number of plants accommodated per unit area in the narrow row spacing than in the plants having wider canopy area (category 1, 2 and 3) (Table 3).

Considering the degree of synchrony in pod ripening, result indicated that plant having 1 branch or less (category 4 and 5) showed synchrony in pod maturity and the plant having 2 branches (category 3) showed partial synchrony in pod ripening (Table 3). Further, the plants which have more than 2 branches (category 1 and 2) showed asynchrony in pod ripening. Finally, it may be concluded that MS with three branches might be the best for maximizing seed yield under recommended plant spacing of $30 \mathrm{~cm} \times 10 \mathrm{~cm}$, while MS only (category 5) or MS with one branch (category 4) might be a good practice regarding the canopy structure and synchrony in pod maturity of mungbean plants.

\section{References}

Ambroszczyk A, Cebula S and Sekara A 2008. The effect of plant pruning on the light conditions and vegetative development of eggplant (Solanum melongena L.) in greenhouse cultivation. Veg. Crops Res. Bull. 68: 57-70.

Arzani K, Bahadori F and Piri S 2009. Paclobutrazol reduces vegetative growth and enhances flowering and fruiting of mature 'J.H. Hale' and 'Red Skin' peach trees. Hort. Environ. Biotech. 50: 84-93.

BARC 2005. Fertilizer recommendation guide. Bangladesh Agric. Res. Council (BARC), Farmgate, Dhaka1215. p. 54.

Davis JM and Estes EA 1993. Spacing and pruning affect growth, yield, and economic returns of staked fresh-market tomatoes. J. Amer. Soc. Hort. Sci. 118: 719-725.

Fakir MSA, Mondal MMA, Ismail MR and Ashrafuzzaman M 2011. Flowering pattern and reproductive efficiency in mungbean. Int. J. Agric. Biol. 13: 966-970.

Heuvelink E 2005. Tomato. Crop production science in horticulture. no. 13. Heuvelink, E. (ed.). CAB International, Wallingford, UK.

Kanyomeka L and Shivut B 2005. Influence of pruning on tomato production under controlled environments. Agric. Trop. Subtrop. 38: 79-83.

Mondal MMA, Hakim MA, Juraimi AS, Azad MAK and Karim MR 2011a. Contribution of morphophysiological attributes in determining the yield of mungbean. Afr. J. Biotech. 10(60): 12897-12904.

Mondal MMA, Fakir MSA, Juraimi AS, Hakim MA and Islam MM 2011b. Effects of flowering behavior and pod maturity synchrony on yield of mungbean. Aust. J. Crop Sci. 5: 945-953.

Mondal MMA, Rahman MA, Akter MB and Fakir MSA 2011c. Effect of defoliation during reproductive stage on yield in mungbean. Legume Res. 34(3): 222-225.

Mondal MMA, Fakir MSA, Ismail MR and Ashrafuzzaman M 2011d. Effect of defoliation on growth, reproductive characters and yield in mungbean. Australian J. Crop Sci. 5(8): 987-992.

Russell DF 1986. MSTAT-C computer package programme, Crop and Soil Science Department, Michigan State University, USA.

Singh G, Sekhon HS, Singh G, Brar JS, Bains TS and Shanmugasundaram S 2011. Effect of plant density on growyh and yield of mungbean genotypes under different environments in India and Taiwan. Int. J. Agric. Res. 6(7): 573-583.

Tah PR and Saxena S 2009. Induced synchrony in pod maturity in mungbean. Int. J. Agric. Biol. 11: 321 324. 